\title{
LUDOBÓJSTWO W IRACKIM KURDYSTANIE W LATACH 80. XX WIEKU I JEGO UMIĘDZYNARODOWIENIE
}

Termin „ludobójstwo” stworzony przez polskiego prawnika Rafała Lemkina oznacza ,[...] zniszczenie narodu lub grupy etnicznej, [...] niekoniecznie jednak oznacza natychmiastowe zniszczenie narodu z wyjątkiem sytuacji, w których dokonywane jest poprzez masowe morderstwa wszystkich członków grupy. Ma raczej na celu skoordynowany plan różnorodnych działań mających na celu unicestwienie grupy samej w sobie $[. .$.$] . [...] Ludobójstwo jest wymierzone przeciwko grupie narodowej jako całości,$ a działania w jego ramach skierowane przeciwko jednostkom, nie jako poszczególnym osobom, ale jako członkom grupy narodowej [...]" (Lemkin, 2013: 110).

Kwestia masowego ludobójstwa dokonanego na przestrzeni lat 80. XX wieku na mniejszości kurdyjskiej zamieszkującej terytorium Iraku, jest stosunkowo mało znana w polskiej literaturze przedmiotu. O ile w mniejszym lub większym stopniu dzieje polityczne tego kraju znalazły odbicie w dorobku światowej historiografii czy politologii i stosunków międzynarodowych, to jednak w widoczny sposób brak jest szczegółowej analizy powyższego zagadnienia w polskiej literaturze dotyczącej problematyki Bliskiego Wschodu. Stosowne dokumenty dotyczące zbrodni dokonanej przez reżim Saddama Husajna na Kurdach znajdują się w zasobach instytucji międzynarodowych (m.in. ONZ), a samo zagadnienie jest bardziej znane w literaturze arabskiej czy anglolub niemieckojęzycznej (Leukenfeld, 2006; Akreyi, 2011; Zebari, 2013; Ghaderi, 2013: 127-128).

Obecne studium problemu jest zatem próbą ukazania genezy, uwarunkowań i przebiegu wydarzeń, które doprowadziły do zorganizowanej częściowej eksterminacji ludności kurdyjskiej na terenie północnego Iraku w ramach szeroko zakrojonej operacji wojskowo-policyjnej pod kryptonimem Al-Anfal $^{1}$.

\section{OKOLICZNOŚCI I PRZEBIEG LUDOBÓJSTWA KURDÓW}

Konflikt iracko-kurdyjski sięga początku lat 20. XX wieku, kiedy Kurdowie zaczęli walczyć o swoje prawa narodowe w ramach powstałego wówczas Królestwa Iraku.

\footnotetext{
1 Słowo pochodzenia arabskiego, nazwa VIII sury Koranu, oznaczające łupy wojenne. Użyte po raz pierwszy przez Proroka Muhammada/Mahometa, który zwrócił się do swoich towarzyszy (ar. Al-Sahaba) słowami: „Tam, jest dobytek Kurajszytów, atakujcie, to co zdobędziecie. Bóg sprawi że będzie Wasze".
} 
Jednak ich starania nie przyniosły oczekiwanych rezultatów. Po objęciu władzy przez lewicową partię Al-Baas (o profilu nacjonalistycznym i wizji państwa typowo unitarnego) w 1963 roku, stosunek nowego rządu irackiego do żądań Kurdów uległ radykalizacji. Mimo iż w 1968 roku na VII Zjeździe partii Al-Baas, jej nowi przywódcy (Ahmed Hassan al-Bakr, Saddam Husajn, Abdul Razzaq Naif, Salih Mahdi Ammash, Ibrahim Abdul Rahman Dawood, Saadoun Ghaidan), którzy doszli do władzy w wyniku zamachu stanu, obiecali zamieszkującym Irak Kurdom prawa narodowe, to jednak nie zamierzali wywiązać się ze złożonych przez siebie wcześniej obietnic. Stąd też, konflikt iracko-kurdyjski trwał przez kolejny rok.

11 marca 1970 r. w wyniku negocjacji pomiędzy obydwiema stronami, podpisano porozumienie, które formalnie zakończyło konflikt, a Kurdowie uzyskali ograniczoną autonomię. Jednak region Kirkuku, bogaty w zasoby ropy naftowej, nadal pozostawał kością niezgody, doprowadzając do ponownych walk pomiędzy stroną iracką a wspieraną przez Iran stroną kurdyjską. Ich kres nastapił 6 marca 1975 r. w wyniku podpisania porozumienia o wyznaczeniu „linii granicznej” między Irakiem a Iranem. Po wybuchu wojny w Zatoce Perskiej pomiędzy Irakiem a Islamską Republiką Iranu (1980-1988), Demokratyczna Partia Kurdystanu (kurd. Partiya Demokrata Kurdistanê) oraz Unia Patriotyczna Kurdystanu (kurd. Yekîtiya Nîştimanî ya Kurdistanê) dostrzegły ponowną szansę na uzyskanie autonomii. Jednak próby negocjacji z władzami irackimi nie powiodły się. Przez cały okres trwania wspomnianego konfliktu w Zatoce Perskiej, Iran w różny sposób wspierał partyzantkę kurdyjską w Iraku. Tuż przed zakończeniem wojny iracko-irańskiej, Saddam Husajn postanowił ukarać Kurdów za ich zaangażowanie po stronie Iranu i przede wszystkim raz na zawsze ,zlikwidować problem kurdyjski” (al-Mas'ala, 2014).

W 1983 roku aparat represji S. Husajna aresztował osiem tysięcy członków rodziny Barzanich, która od lat 20. XX wieku nie ustawała w walkach o prawa Kurdów w Iraku. Saddam Husajn chciał pozbyć się tego klanu - jakże ważnego w historii Kurdów $\mathrm{w}$ walce o ich samostanowienie. Na początku przesiedlono ich na pustynię przy granicy z Arabią Saudyjską. Do 2003 roku ich los nie był znany. Dopiero po upadku reżimu Saddama Husajna, dzięki komisjom badającym masowe groby ofiar reżimu, wyjaśnione zostały między innymi tragiczne losy owych ośmiu tysięcy członków rodziny Masuda Barzaniego, obecnego prezydenta federacji kurdyjskiej w Iraku, zamordowanych w bestialski sposób i pochowanych na pustyni. Ich szczątki zostały wykopane i do dziś przekazywane są władzom kurdyjskim w północnym Iraku, a następnie chowane są z wojskowymi honorami (ibidem).

Wojna iracko-irańska, trwająca osiem lat, pogrążła oba państwa w ruinie gospodarczej. Z uwagi na brak stosownego porozumienia ze strony irańskiej, władze irackie nie mogły zakończyć wojny, stąd też Saddam Husajn rozpoczął walkę z użyciem broni chemicznej. Operacja Al-Anfal jest zespołem działań wojskowych, w których irackie siły zbrojne dokonały wielu krwawych czystek i pacyfikacji przy pomocy pierwszej i piątej Dywizji Gwardii Republikańskiej (arab. al-Haras al-dżemhori) w Kirkuku i Irbilu, ponadto specjalnej jednostki sił bezpieczeństwa, a także Armii Ludowej (arab. $a l-D \dot{e z j s z} a l-S z a a b i)^{2}$. Podczas walk siły te używały wszelkich dostępnych rodzajów

2 Były to oddziały o charakterze paramilitarnym, utworzone w czasie wojny iracko-irańskiej, rekrutowane na rozkaz reżimu spośród rodzin irackich, w celu wsparcia armii rządowej. 
broni, m.in. czołgów, ciężkiej artylerii, sił powietrznych i broni chemicznej. W sytuacji, gdy Saddam Husajn nie mógł poradzić sobie z ludnością kurdyjską na północy kraju, ostatecznie podjął decyzję o eksterminacji narodu kurdyjskiego, bez względu na wiek, płeć i lojalność wobec władzy irackiej, stosując zasadę odpowiedzialności zbiorowej. Wystarczyło, że jeden z członków rodziny był partyzantem, a kara dotykała pozostałych krewnych (Jomma, 2001: 85).

Władze irackie rozpoczęły wspomnianą operację $A l$-Anfal, a jej dowództwo przekazano kuzynowi Saddama Husajna, Alemu Hassanowi Al-Madżidowi, któremu powierzono nieograniczoną władzę na obszarach kurdyjskich, na podstawie decyzji nr 160 uchwalonej przez dowództwo Rady Rewolucyjnej (arab. Madżlis Qiadet al-sawra) 29 marca 1987 r. Sam Al-Madżid wydał dwie dyrektywy, na mocy których dowodzone przez niego siły miały wymordować wszystkich Kurdów przebywających w „strefach zakazanych", przez niego odgórnie wyznaczonych. Druga dyrektywa została rozszerzona o szczegółowy opis masowych mordów, które miały zostać przeprowadzone na ludności cywilnej, ponadto o rozkazy bombardowania w dzień i w nocy wiosek kurdyjskich oraz zatrzymania i przesłuchania przez służby bezpieczeństwa (arab. Muhabarat) wszystkich ocalałych w wieku od 15 do 70 lat. Muhabarat miał wymusić na nich różnymi sposobami potrzebne informacje, a następnie dokonać egzekucji.

Po wydaniu rozkazu ataku gazowego na miasteczko Halabdża w 1988 r., Al-Madżid z czasem stał się u Kurdów powszechnie znany, złowrogi przydomek Chemiczny Ali. Władze irackie czuły się wówczas zupełnie bezkarne. Wiadomości o sukcesach i „bohaterskich” czynach armii przeciwko „zdrajcom” i „wrogom” oraz ,,agentom obcych państw", pojawiały się w mass mediach na terytorium całego kraju. Zmobilizowano duchownych w meczetach, by ogłosić „dżihad przeciwko heretykom”, jakimi według nich byli Kurdowie. Partia Al-Baas i instytucje państwowe co roku organizowały m.in. imprezy i uroczystości w rocznicę tych wydarzeń. Imieniem Al-Anfal zaczęto także nazywać szkoły oraz różnego rodzaje instytucje. Sztab generalny armii i oficjalna propaganda władz usprawiedliwiały działania, które były skierowane przeciwko władzom irańskim oraz miejscowym „zdrajcom”, którzy z nimi współpracują. Ali Hassan Al-Madżid zdobył niepodzielną władzę, bliską władzy samego prezydenta kraju, Saddama Husajna. Polityka Al-Madżida była wykonywana pod hasłem ,rozwiązania kwestii kurdyjskiej” oraz „likwidacji sabotażystów” (Iraq's, 1993). W ciagu dwóch lat sprawowania przez niego władzy w Kurdystanie, poczynania Al-Madżida można przedstawić w następujących punktach (Kelly, 2008: 33-36):

1) masowe egzekucje i eksterminacja dziesiątek tysięcy cywilów bez względu na wiek i płeć;

2) masowe użycie broni chemicznej, gazu bojowego, tj. sarinu i gazu musztardowego w ponad czterdziestu miejscach;

3) całkowite zniszczenie ponad czterech tysięcy wiosek oraz ośrodków administracyjnych przez bombardowanie i palenie;

4) niszczenie obiektów publicznych (szkoły, meczety, kościoły chrześcijan różnych obrządków);

5) ograniczenie ludności dostępu do wody - niszczenie studni oraz źródeł wody pitnej;

6) konfiskata majątku ludności przez armię; 
7) aresztowanie ludności wiejskiej i oskarżanie jej o przebywanie w miejscach zakazanych, mimo że znajdowali się w swoich domach;

8) aresztowanie dziesiątek tysięcy niewinnych kobiet i dzieci oraz starców w obozach na pustyni w środkowym i południowym Iraku, gdzie panowały wyjątkowo ciężkie warunki przez wiele miesięcy. Większość z nich zmarła z powodu głodu i chorób;

9) fakt, że do dziś nie są znane losy wielu kurdyjskich kobiet, które zostały sprzedane do innych krajów arabskich. Ich rodziny wciąż czekają na jakąkolwiek wiadomość. Inne z nich zostały zgwałcone przez żołnierzy irackich, lecz proceder ten nie został nagłośniony, ponieważ w kulturze krajów bliskowschodnich gwałt na kobiecie sprowadza hańbę na całą jej rodzinę;

10) przymusowe przesiedlenia setek tysięcy mieszkańców do tzw. „ośrodków nowoczesnych" dokonane po zniszczeniu wsi;

11) zniszczenie infrastruktury we wsiach kurdyjskich, mające na celu uniemożliwienie odbudowy zniszczonych obszarów (Ibidem).

Operacja Al-Anfal objęła swoim zasięgiem sześć regionów geograficznych. 23 lutego 1988 r. rozpoczął się pierwszy etap ataku armii irackiej na obszary Serkllo i Berkllo oraz pozycje zajmowane przez partię patriotyczną Kurdystanu. Trwał on sześć tygodni. Drugi etap nastąpił w regionie Qeredag, rozpoczął się 22 marca 1988 r. i trwał do końca miesiąca. Trzeci etap dotyczył obszaru Germian w muhafazacie Kirkuk. Rozpoczął się 7 kwietnia i trwał do 20 kwietnia 1988 r. Była to najbardziej dotkliwa ze wszystkich dotychczasowych operacji ze względu na zasięg terytorialny oraz straty w liczbie ludności. W ten sposób dokonano czystek etnicznych, gdyż główny spór między Kurdami a Arabami dotyczył obszaru Kirkuku, który posiada bogate złoża ropy naftowej. W czwartym etapie operacja objęła okolice rzeki Mały Zab. Atak trwał od 3 do 8 maja 1988 r. Piąty, szósty i siódmy etap dotyczył obszaru górskich dolin Shaqlawa i Rawanduz w okolicach muhafazatu/parêzgeh (arabski, kurd., odpowiednik polskiego terminu województwo) Irbil i rozpoczął się 15 maja 1988 r., a trwał do 26 sierpnia 1988 r. Jednak władze nie zdołały zakończyć operacji pomyślnie ze względu na opór partyzantów. Ostatni etap operacji Al-Anfal rozpoczął się po zakończeniu wojny iracko-irańskiej. Trwał od 25 sierpnia 1988 r. do 6 września 1988 r. (Koivunen, 2013: 46-48).

Z relacji rzecznika Departamentu Stanu USA Petera W. Galbraitha wynika, że kiedy za zgodą władz irackich udał się on w kierunku Kurdystanu zauważył między miejscowością Jalawla i miastem Sulajmanijja około 29 całkowicie zniszczonych wiosek, a w innych trwający proces ich niszczenia przy użyciu buldożerów. Skala zniszczeń obejmowała nie tylko budynki zamieszkane przez ludzi, ale również budynki użyteczności publicznej, takie jak meczety, szkoły. Dopuszczano się także dewastacji nagrobków, łamania słupów energetycznych. Aż do miasta Sulajmanijja ani na polach, ani w wioskach nie było żadnych śladów ludności. W celu kontroli mieszkańców, armia zbierała ludność w dolinach, w których trwały prace przy budowie nowych miasteczek. Miasteczka te niczym nie różniły się od obozów koncentracyjnych (Ibidem).

Do 2 sierpnia 1991 roku władze irackie unicestwiły ponad cztery tysiące miasteczek i wiosek w Kurdystanie. Na wschodnim obszarze Kurdystanu armia iracka zniszczyła także takie miejscowości jak: Qala Diza, Halabdża i Seyed Sadiq. Z 75000 km² powierzchni Kurdystanu irackiego, aż $45000 \mathrm{~km}^{2}$ objęte było zakazem zamieszkiwania. Duży odsetek ludności z tych terenów, jeżeli ludzie ci mieli szczęście, przesiedlono na 
obszary arabskie w środkowym i południowym Iraku. Po upadku reżimu irackiego w 2003 roku, minister ds. praw człowieka w Kurdystanie, Muhamed Ihsan przewodniczył zespołowi prokuratorów, którzy znaleźli masowe groby na terenach arabskich, w których pogrzebane były tysiące ofiar kurdyjskich. Ofiary te miały opaski na oczach, skrępowane ręce i zostały zabite strzałem w tył głowy (Galbraith, 2006: 36-37). 15 marca 1988 roku, siły kurdyjskie i irańskie wyzwoliły miasteczko Halabdża. W odwecie władze irackie zdecydowały się następnego dnia na użycie broni chemicznej. Zginęło ponad pięć tysięcy osób, głównie ludność cywilna.

Administracja prezydenta Ronalda Reagana była poinformowana o zniszczeniach w Kurdystanie przez raport P. W. Galbraitha „Wojna w Zatoce Arabskiej: Stany Zjednoczone po jednej z dwóch stron" oraz przez dokument złożony w kwietniu $1988 \mathrm{r}$. przez Jalal'a Talabaniego - przewodniczącego Partii Patriotycznej Kurdystanu, o użyciu broni chemicznej przez Irak przeciwko ludności kurdyjskiej, oraz wcześniej także przeciwko armii irańskiej. Jednakże strona amerykańska nie wykazała zainteresowania sprawa. Stany Zjednoczone były informowane przez Centralnq Agencję Wywiadowcza (CIA) wcześniej o posiadaniu, jak i używaniu przez Irak broni chemicznej (Galbraith, 2006: 40).

Światowa opinia publiczna ostro skrytykowała atak dokonany przez siły irackie. $\mathrm{Na}$ forum Kongresu Stanów Zjednoczonych, ówczesny senator George Mitchell, złożył projekt potępiający iracki reżim. Naraził się tym samym R. Reaganowi, który popierał wówczas politykę proiracką. Pomimo wielu informacji na temat używania broni chemicznej przez Irak, strona amerykańska uważała, że wina leży zarówno po stronie Iraku, jak i Iranu. Wydaje się to dość trudne do udowodnienia, ponieważ wówczas Iran nie miał żadnych interesów politycznych żeby działać przeciwko Kurdom walczącym u boku armii irańskiej. Sprawa ta znalazła szeroki oddźwięk w mediach zachodnich, w dużym stopniu dzięki diasporze kurdyjskiej mieszkającej na zachodzie. Po zakończeniu wojny iracko-irańskiej w sierpniu 1988 r. nadal trwała pacyfikacja wiosek i miast kurdyjskich, przez co wielu Kurdów przekraczało granicę Iranu oraz Turcji, w obawie przed zagładą ze strony armii irackiej, która wciąż stosowała broń masowego rażenia (Koivunen, 2013: 55-57).

Pracownik Departamentu Stanu, Peter W. Galbraith próbował przekonać senatorów do nałożenia sankcji gospodarczych na Irak. Napisał wstępny projekt ustawy polegający na zakazie importu ropy naftowej z Iraku do Stanów Zjednoczonych, zniesieniu gwarancji rządowej na eksport towarów do Iraku, zakazie eksportu wszelkich towarów amerykańskich do Iraku oraz zmniejszeniu pomocy finansowej. Nazwał ten projekt The Prevention of Genocide Act (ustawa z 1988 r. o zapobieganiu aktom ludobójstwa) (Galbraith, 2006: 42). Aby potwierdzić swoje dowody o użyciu broni chemicznej przeciwko ludności kurdyjskiej, wybrał się na pogranicze turecko-irackie, gdzie znajdowali się uchodźcy kurdyjscy z Iraku. Rozmowy trwały ponad tydzień, z rozmów z naocznymi świadkami dowiedział się o przebiegu całej akcji (Ibidem).

12 września 1988 r. rząd amerykański stwierdził jednak, że jest zbyt wcześnie, aby podjać stosowne kroki przeciw Saddamowi Husajnowi. Wycofał się tym samym z projektu Petera W. Galbraitha, ponieważ wygrały interesy polityczne, ekonomiczne i realna polityka Stanów Zjednoczonych. Działania skierowane przeciwko Irakowi godziły w interesy farmerów amerykańskich, gdyż Irak importował bardzo duże ilości ryżu 
oraz zbóż ze Stanów Zjednoczonych. Te grupy interesu naciskały na rząd amerykański, aby ten nie nakładał embarga na Irak. Znaczące grupy interesu w Stanach Zjednoczonych uważały, że po zakończeniu wojny iracko-irańskiej Irak będzie wydawał miliardy dolarów na odbudowę swojego kraju, co dawało Ameryce ogromną szansę na udział w odbudowie. Było to nierealne myślenie, ponieważ Irak był zadłużony na ponad 100 miliardów dolarów (Kelly, 2008: 75).

Po ataku Iraku na Kuwejt w 1990 r., rząd amerykański został zmuszony do spłaty długu wobec swoich farmerów. Administracja amerykańska chciała „przymknąć oczy” na atak z użyciem broni chemicznej zrealizowany przez Irak przeciwko Kurdom, gdyż była przekonana, że jest w stanie zmienić postępowanie dyktatora Saddama Husajna, uważała również, że Irak jest nadal „partnerem strategicznym” dla Stanów Zjednoczonych (Ibidem).

Kiedy Saddam Husajn zaczął grozić władzom Izraela użyciem broni chemicznej, Kongres amerykański wznowił swoje wysiłki, by nałożyć embargo na Irak wiosną 1990 roku. W ten sposób członkowie Kongresu chcieli zmusić władze Iraku do podporządkowania się prawu międzynarodowemu. Pomoc finansowa dla Iraku miała być uzależniona od respektowania postanowień konwencji genewskiej o zakazie używania broni chemicznej oraz od Uktadu o nierozprzestrzenianiu broni jadrowej (Galbraith, 2006: 119).

Ówczesny prezydent Stanów Zjednoczonych George H. W. Bush, sprzeciwiał się projektowi nałożenia embarga na Irak, a wręcz podwoił pomoc finansową dla Iraku. 25 lipca 1990 r., mimo sprzeciwu administracji Busha, a z ogromnym poparciem senator Nancy Landon Kassebaum-Baker ze stanu Kansas, która stwierdziła, że „rolnicy z jej stanu nie będą sprzedawać swoich żniw do kraju, w którym używana jest broń chemiczna i w którym torturowani są ludzie", zostało nałożone embargo na Irak (Ibidem).

\section{OKOLICZNOŚCI WYBUCHU I PRZEBIEG POWSTANIA KURDYJSKIEGO}

Saddam Husajn chciał zniwelować napięcie związane z sytuacją gospodarczą po wojnie z Iranem. Postanowił więc zdobyć przywództwo w świecie arabskim oraz poprawić sytuację ekonomiczną kraju poprzez zdobycie Kuwejtu bogatego w złoża ropy naftowej. 16 lipca 1990 r. władze Iraku wystosowały otwarty list do Ligi Państw Arabskich, w którym oskarżyły Kuwejt o „kradzież” ropy ze złóż znajdujących się na polu naftowym Ar-Rumaila. Według przedstawicieli Iraku należało ono do Iraku, mimo że pięciokilometrowy południowy skrawek pola leży na terytorium Kuwejtu (Bulloch, Morris, 1991: 52). Władze Iraku oskarżyły również Kuwejt, posiadający w tamtym okresie jedynie siedemnastotysięczną armię, o „agresję” przeciw liczącej milion żołnierzy armii irackiej. Saddam Husajn był niezadowolony z postawy władz Kuwejtu, które zwiększyły wydobycie ropy naftowej, co spowodowało spadek cen ropy na rynkach światowych (al-Hazraji, 2014: 87-95).

Władze Kuwejtu domagały się zwrotu pożyczki z czasów wojny iracko-irańskiej, lecz Irak nie miał zamiaru spłacać swojego długu, ponieważ Husajn uważał, że te pieniądze stanowią, ,bezzwrotną pomoc”. Irak miał być wówczas ,tarczą obronną” dla reszty państw arabskich przed ekspansją rewolucji islamskiej w Iranie (Dziekan, 2002: 186). 
2 sierpnia 1990 r. armia iracka dokonała inwazji na Kuwejt, w odpowiedzi na cierpienie Kuwejtczyków, rząd Stanów Zjednoczonych wysłał okręty wojenne do Zatoki Perskiej, zaś Związek Radziecki zaprzestał wysyłania broni do Iraku. W dniu rozpoczęcia wojny z Kuwejtem, Rada Bezpieczeństwa ONZ uchwaliła rezolucję nr 660 żądającą natychmiastowego wycofania się wojsk irackich z terytorium Kuwejtu. 7 sierpnia 1990 r. Rada Bezpieczeństwa ONZ uchwaliła kolejną rezolucję nr 661 nakładającą embargo na handel, obroty finansowe i dostawy sprzętu wojskowego i broni do Iraku. Wprowadzenie embarga okazało się bardzo dotkliwe dla zwykłych obywateli tego kraju, którzy zostali pozbawieni podstawowych środków do życia, lekarstw i sprzętu w szpitalach. Embargo, które obowiązywało aż do 2003 roku spowodowało wzrost śmiertelności obywateli, zwłaszcza niemowląt, oraz doprowadziło kraj do ruiny gospodarczej. 29 listopada Rada Bezpieczeństwa ONZ uchwaliła rezolucję nr 678 zezwalającą na użycie siły w celu usunięcia wojsk irackich z terenu Kuwejtu. Wystosowała również ultimatum do władz irackich z żądaniem wycofania wojsk z Kuwejtu do 15 stycznia 1991 r. (Resolution, 1990: par. 2).

Po odrzuceniu ultimatum przez Irak, Stany Zjednoczone zaczęły tworzyć wielką koalicję antyiracka. W jej skład wchodziło 35 państw, w tym niektóre państwa arabskie. Konsekwencją wojny iracko-kuwejckiej było rozpoczęcie procesu pokojowego między państwem Izrael, a niektórymi państwami arabskimi. W październiku 1991 roku odbyła się w Madrycie konferencja pokojowa pod auspicjami USA i ZSRR. Spotkali się na niej przedstawiciele Izraela, Syrii, Libanu, Jordanii oraz Palestyńczyków.

Po klęsce armii irackiej w Kuwejcie siły kurdyjskie przypuszczały, że będą w stanie pokonać osłabione siły reżimu. 15 lutego 1991 George H. W. Bush na spotkaniu z pracownikami fabryki rakiet Patriot powiedział „Jest inny sposób, by zaprzestać rozlewu krwi, a jest nim obalenie rządu Saddama Husajna przez wojsko i naród iracki”. Transmisja z wypowiedzią prezydenta obiegła cały świat, dzięki mass mediom zachodnim oraz arabskim. Po przemowie George H. W. Busha, ludność szyicka i kurdyjska jednoznacznie zrozumiała przekaz prezydenta Stanów Zjednoczonych. Zdaniem autora, powstanie nie było sprowokowane tylko i wyłącznie wypowiedzią George’a H. W. Busha, lecz naiwnością ludności irackiej zakładającej, że państwa koalicji antyirackiej „na pewno" wspomogą ich w powstaniu przeciwko dyktaturze Saddama Husajna.

Państwa zachodnie nie miały jednak na celu (jak się niedługo potem okazało) obalenia reżimu irackiego, ale przede wszystkim wyzwolenie okupowanego Kuwejtu, ograniczenie wpływów irackich $\mathrm{w}$ tej części Zatoki posiadającej jedne z najbogatszych na świecie złóż ropy. Obalenie reżimu nie wchodziło jednak w grę (co było powszechnym zaskoczeniem dla światowej opinii publicznej), ponieważ quasi-totalitarny reżim S. Husajna gwarantował stabilizację oraz powstrzymanie wpływu Iranu na ludność szyicką w południowej części kraju. Ta bowiem z łatwością mogłaby przejąć wówczas mocno osłabioną i zdestabilizowaną po upadku Saddama władzę i wydatnie rozszerzyć wpływy państwa ajatollahów. Na taki scenariusz nie mogłyby się wówczas zgodzić ani państwa zachodnie, ani też państwa arabskie położone nad Zatoką Perską (Muhammad, 2011). Dopiero w perspektywie najbliższej dekady okazało się, że pozostawienie osłabionego Husajna przy władzy było błędem, i że potrzebna będzie kolejna interwencja militarna w 2003 roku, tym razem prowadzona pod sztandarem wojny z terroryzmem, której dalszych, tragicznych dla Iraku konsekwencji nikt wtedy jeszcze nie przewidywał. 
2 marca 1991 r. doszło do wybuchu wielkiego powstania ludności szyickiej zamieszkującej obszar od Basry w kierunku środkowego Iraku. Powstanie na południu zostało krwawo stłumione po 10 dniach, kiedy to Saddam Husajn wysłał elitarne dywizje Gwardii Republikańskiej, które składały się głównie z Arabów (sunnitów) pod dowództwem oficerów pochodzących z klanu Saddama Husajna. De facto, powstańcy zostali przez USA i koalicję skazani na łaskę lub niełaskę Husajna w wyniku bezwzględnych realiów ,wielkiej polityki”. Po dyktatorze trudno się jednak było spodziewać jakiejkolwiek pobłażliwości tak dla szyitów, jak i potem dla „kurdyjskich zdrajców".

Z zeznań naocznych świadków armii amerykańskiej, która stacjonowała wówczas w miastach i miasteczkach szyickich, dowiadujemy się o masowych okrucieństwach armii irackiej wymierzonych w ludność szyicka. Mimo zakazu używania lotnictwa, co było jednym z punktów porozumienia zakończenia wojny między Irakiem a Stanami Zjednoczonymi, Husajn do stłumienia powstania użył m.in. silnie uzbrojonych śmigłowców bojowych. Szyici byli zabijani poprzez powieszenie, spalenie żywcem, bądź rozstrzelanie, a także podczas bombardowania miast i miasteczek. Armia amerykańska miała związane ręce, ponieważ w żaden sposób nie mogła ona pomóc ofiarom zbrodni. Żołnierze amerykańscy nie otrzymali od swoich dowódców rozkazu interwencji. Szacuje się, że między marcem a wrześniem 1991 roku śmierć poniosło około 300 tys. szyitów (Gulf War, 2014).

Natomiast Kurdowie na północy kraju wzniecili powstanie 6 marca 1991 r., kiedy grupa ludzi zaatakowała siedzibę Socjalistycznej Partii Odrodzenia Arabskiego (Al-Baas) w miejscowości Rani. 14 marca rebelianci przejęli kontrolę nad większością obszaru Kurdystanu, a 21 marca nad Kirkukiem. Kurdowie zdobyli siedziby wywiadu irackiego, gdzie skonfiskowali 14 ton dokumentów, które oficjalnie potwierdziły eksterminację Kurdów w latach osiemdziesiątych. Pod koniec marca Saddam Husajn skierował swoje siły (Gwardię Republikańską) na północ kraju, która znalazła się pod kontrolą Kurdów. Dyktator ponownie zaczął zdobywać miasta. Ludność kurdyjska w obawie przed masowymi mordami zaczęła uciekać do Iranu i Turcji. Kurdyjscy uchodźcy maszerowali przez góry, gdzie codziennie wiele osób traciło życie, głównie dzieci i starcy. Opinia publiczna na zachodzie, wstrzaśnięta reportażami z miejsc exodusu, naciskała na wojska koalicyjne, aby te wspomogły uchodźców. Pod naciskiem opinii publicznej i mass mediów George H. W. Bush wydał swojemu wojsku rozkaz interwencji w północnym Iraku. W 1991 roku władze Francji, Wielkiej Brytanii i Stanów Zjednoczonych zwróciły się do Rady Bezpieczeństwa ONZ o uchwalenie rezolucji. 5 kwietnia 1991 roku ONZ uchwaliła rezolucję nr 688 stwarzającą możliwość ochrony ludności kurdyjskiej, przywrócenia stabilizacji i powstrzymania represji dokonywanych w północnym Iraku, a także rozpoczęcia interwencji zbrojnej (Resolution, 1991: par. 1, 2, 4). Operacja nosiła nazwę Provide Comfort (Clary, 1994). Dzięki rozpoczęciu akcji humanitarnej sytuacja Kurdów powoli zaczęła się poprawiać. W ten sposób została zatrzymana wielka machina eksterminacji Kurdów podjęta przez reżim iracki.

Francja, Wielka Brytania i Stany Zjednoczone wykorzystały rezolucję nr 688 do ustanowienia zakazu lotów wojskowych samolotów i śmigłowców irackich nad terytorium rozciagającym się na północ od 36 równoleżnika, jak również przekraczania przez wojska lądowe wyznaczonych granic. Jednocześnie utworzono jednostki wojskowe 
złożone z sił lądowych i powietrznych Stanów Zjednoczonych, Wielkiej Brytanii oraz Francji, które zostały tam rozlokowane. Ich mandat ograniczony został do trzech miesięcy. Pod koniec lipca 1991 r., po stopniowym wycofaniu większości sił pozostawiono tam jedynie grupy obserwatorów mających nadzór nad przestrzeganiem przez władze irackie postanowień wspomnianej rezolucji. Tym samym, Kurdystan funkcjonował jako „strefa bezpieczeństwa” i de facto jako zalążek przyszłej autonomii dla tamtejszej ludności (Galbraith, 2006: 65).

Niespodziewanie, we wrześniu 1991 r. Saddam Husajn wycofał swoją armię oraz administrację państwową z dwóch głównych miast kurdyjskich - Sulajmanijja i Irbil. Nałożył on również embargo na rejony kurdyjskie. Miał także nadzieję, że nowo powstała administracja na tym terenie szybko upadnie bez pomocy z Bagdadu. Dzięki temu, S. Husajn mógłby sprawować w pełni władzę zwierzchnią nad irackim Kurdystanem.

19 maja 1992 r. przy poparciu państw sprzymierzonych, Partia Demokratyczna Kurdystanu (50,8\% miejsc) oraz Unia Patriotyczna Kurdystanu (49,2\% miejsc) utworzyły parlament, czemu przyglądali się obserwatorzy z państw EWG. Poza przedstawicielami tych partii znaleźli się $\mathrm{w}$ nim przedstawiciele ugrupowań asyryjskich i ugrupowań Turkmenów, zamieszkujących Kurdystan iracki (Jomma, 2001: 86-87). Powołano rząd, na czele którego stanął Fuad Masum (pełniący następnie od 24 lipca $2014 \mathrm{r}$. funkcję prezydenta Iraku). Władza nie działała w pełni skutecznie z powodu sankcji gospodarczych wprowadzonych przez Irak, które miały zmusić Kurdów do porzucenia planów o stworzeniu federacji. Problem polegał również na tym, że państwa ościenne (Turcja, Syria, Iran) skutecznie działały na destabilizację nowego organizmu państwowego. Istniały obawy, że wśród Kurdów zamieszkałych na terytorium tych państw obudzi się duch nacjonalistyczny i rewindykacyjny. Mimo utrudnień ze strony władz i państw sąsiedzkich, sytuacja Kurdów wyglądała stosunkowo poprawnie. Pojawiło się jednak wiele trudności w pokojowej egzystencji obszaru irackiego Kurdystanu (al-Akrad, 2014).

Po pierwsze, dały się odczuć ekonomiczne skutki embargo nałożonego na Irak. Po drugie, funkcje administracyjne $\mathrm{w}$ niektórych przypadkach przejęli ludzie mający przeszłość partyzancką, za to pozbawieni niezbędnego doświadczenia i wiedzy fachowej. Po trzecie, w wyniku cichej interwencji Iranu w wewnętrzne sprawy Kurdów doszło tam do konfliktu między zwolennikami Demokratycznej Partii Kurdystanu (DPK) a popierającymi Unię Patriotyczną Kurdystanu (UPK), który następnie przerodził się w krótkotrwałą wojnę domową (1993-1994). Zginęło podczas niej kilka tysięcy osób po obu stronach konfliktu. Dopiero międzynarodowy arbitraż zapewnił porozumienie i krótkotrwałe wygaszenie walk. Dodatkowo jeszcze w samym Iranie doszło do przypadków ataków sił lądowych i lotnictwa na obszary kurdyjskie. Stamtąd irańscy peszmergowie udawali się na teren sąsiedniego Iraku w celu uzyskania schronienia, co zazwyczaj skutkowało pościgiem, który niekiedy sięgał do $50 \mathrm{~km}$ w głąb terytorium irackiego Kurdystanu. Powodem takiej polityki ze strony władz z Teheranu był fakt, że oskarżały one Demokratyczną Partię Kurdystanu o „wspieranie partyzantki kurdyjskiej" na terenie Iranu. W tym czasie PDK rozpoczęła negocjacje z rządem Iraku, bo tam spodziewała się znaleźć drogę do dalszych ustępstw politycznych, a z kolei Unia Patriotyczna Kurdystanu uważała, że rozwiązanie kwestii kurdyjskiej należałoby szukać przy poparciu Iranu oraz państw europejskich i USA (ibidem). 
14 kwietnia 1995 r. zainicjowany został przez ONZ na mocy rezolucji nr 986 program „Ropa za żywność” (ang. Oil for Food Programme), który zakładał, że dochody uzyskane przez Irak ze sprzedaży ropy naftowej zostaną przekazane na zakup żywności dla ludności tego kraju (Resolution, 1995: par. 8). Istotnym zastrzeżeniem było przeznaczenie z ogólnej sumy 13\% dla powstałej niedawno quasi autonomii kurdyjskiej. Rezolucja weszła w życie w 1996 roku, co na powrót ożywiło niedawny konflikt wewnętrzny wśród Kurdów. Jego skutkiem był podział wewnętrzny obszaru kurdyjskiego na dwie zwalczające się części i dwie równoległe administracje, co ma odbicie do chwili obecnej. Za pośrednictwem ówczesnej amerykańskiej sekretarz stanu Madeleine Albright doszło w 1998 r. do kolejnego porozumienia pokojowego, zawartego w Waszyngtonie między przedstawicielami obydwu skłóconych frakcji kurdyjskich, DPK i UPK (al-Akrad, 2014).

Dalsze pogłębianie procesu dążenia do emancypacji irackich Kurdów nie leżało w interesie państw ościennych: Turcji, Iranu i Syrii, które obawiały się, że może to mieć negatywny skutek dla przyszłej cesji ich własnych terytoriów zamieszkanych przez Kurdów. Stąd też została zintensyfikowana wzajemna współpraca ministrów spraw zagranicznych i grup eksperckich w monitorowaniu problemu kurdyjskiego i organizacji co 6 miesięcy regularnych spotkań roboczych dla zapobieżenia powstania przyszłego państwa kurdyjskiego. Ten problem stał się we wzajemnych kontaktach swego rodzaju „racją stanu” z uwagi na „zachowanie jedności terytorialnej i bezpieczeństwa regionalnego”, jak również „uniemożliwienie dalszej współpracy między Kurdami zamieszkującymi wyżej wymienione państwa". Po raz pierwszy do podobnego spotkania doszło w listopadzie 1992 roku. To jednak zostało odebrane przez rząd w Bagdadzie za „niczym nie uzasadnioną ingerencję w wewnętrzne sprawy Iraku”, tym bardziej, że podstawą politycznej jego egzystencji był konsekwentnie unitarny charakter państwa. Władze irackie okazały niezadowolenie z faktu, że nie były zapraszane do rozmów tym bardziej, że spotkania dotyczyły kwestii Kurdów zamieszkałych w ramach państwa irackiego. Podjęte wówczas ustalenia między wspomnianymi wyżej państwami zakładały na tych spotkaniach następujące kluczowe zagadnienia:

- zachowanie na stałe terytorialnej jedności obszaru Iraku;

- brak zaangażowania i ingerencji w wewnętrzne sprawy Iraku;

- wzajemne konsultacje dotyczące aktualnej sytuacji na obszarze północnego Iraku w celu ,powstrzymania anarchii i chaosu, które zagrażają stabilizacji w regionie”.

To wywołało ze strony Kurdów oficjalną reakcję - wezwali oni rządy Turcji, Iranu i Syrii do „przestrzegania praw i rozwiązania problemu swoich obywateli pochodzenia kurdyjskiego", poza tym jednoznacznie stwierdzili, że „nie mają zamiaru ingerowania w wewnętrzne sprawy państw ościennych" (Ibidem).

Natomiast wśród państw wchodzących w skład Ligi Państw Arabskich nie było jednolitego stanowiska w sprawie kwestii kurdyjskiej. Można mówić o dwóch rodzajach motywacji, która kierowała przywódcami krajów arabskich czy muzułmańskich popierających dążenia Kurdów. Pierwszą z nich była wrogość wobec irackiego reżimu oraz chęć osłabienia Husajna od wewnątrz poprzez popieranie partyzantów kurdyjskich walczących w Iraku. Państwami którymi kierowała taka motywacja były Syria, która od połowy lat siedemdziesiątych XX wieku dozbrajała Kurdów czy Iran, który również popierał Kurdów mieszkających w Iraku i miał ku temu swój interes wynikający z woj- 
ny toczonej z Irakiem od 1980 do 1988 roku. Państwom tym oczywiście nie zależało na rozwiązaniu kwestii kurdyjskiej, a jedynie na taktycznym wykorzystaniu Kurdów do swoich rozgrywek i interesów politycznych. Inny rodzaj motywacji kierował natomiast takimi państwami jak Egipt za czasów Gamala Abdul Nasera, który dążył do połączenia Egiptu, Syrii i Iraku i próbował rozwiązać kwestię kurdyjską naciskając na władze irackie, by te przyznały Kurdom autonomię. Bardziej kontrowersyjne i odważne stanowisko reprezentował libijski przywódca Muammar al-Kaddafi, który uważał, że Kurdom należy się pełne samostanowienie, wobec czego chętnie pomagał finansowo i dozbrajał kurdyjską partyzantkę. Pozostałe państwa arabskie były zaś zgodne co do jednego: potrzeby zachowania jedności terytorialnej Iraku, brak zgody na jakikolwiek podział lub secesję, czy w formie federacji, czy konfederacji. Jedynym ustępstwem była dosyć ogólna deklaracja o „zachowaniu praw przez ludność kurdyjską” (Mukhemer, 1999).

Kwestia ludobójstwa Kurdów była pomijana na konferencjach Organizacji Współpracy Islamskiej. Najlepszym tego przykładem była konferencja, która odbyła się w 1988 roku w Ammanie, tuż po ataku chemicznym w miejscowości Halabdża, podczas której temat ataku nie został nawet poruszony, a Liga Państw Arabskich w pełni solidaryzowała się z Irakiem potępiając światowe media, które donosiły o użyciu broni chemicznej przeciwko Kurdom twierdząc, że mają one na celu zdyskredytowanie Iraku w oczach opinii publicznej. W tej sytuacji Kurdom nie pozostało nic innego jak zwrócić się o pomoc i nawiązanie współpracy ze światem zachodnim. Próby takie podejmowane przez główne partie kurdyjskie były skazane na niepowodzenie, gdyż do momentu inwazji Iraku na Kuwejt w 1990 roku państwa zachodu współpracowały z Irakiem i innymi państwami arabskimi oraz sprzedawały im broń.

Wówczas Kurdowie zaczęli powoli wykorzystywać wzajemną niechęć do siebie przywódców państw arabskich oraz ich rozbieżne opinie w sprawie polityki Saddama Husajna po aneksji Kuwejtu przez Irak. Taka tendencja utrzymywała się także w kolejnych latach, nawet po upadku irackiego reżimu w 2003 roku. Choć w latach 90. XX w. aktywność Kurdów na scenie politycznej była dość ograniczona ze względu na ich słabą sytuację gospodarczą, podział obszaru kurdyjskiego na dwie strefy, jednej w Irbilu a drugiej w Sulejmanija, oraz brak stabilizacji w regionie, to Kurdowie zyskali sympatię opinii międzynarodowej i mogli liczyć na ograniczoną pomoc finansową na cele administracyjne. Kurdowie dążyli do uzyskania akceptacji państw Zachodu i chcieli być postrzegani jako ich strategiczny sojusznik pokazując, że zależy im na przestrzeganiu praw człowieka, stworzeniu demokratycznych instytucji państwowych oraz doprowadzeniu do stabilizacji i pokoju na kontrolowanych przez nich obszarach. Taka polityka dała wymierny efekt po upadku reżimu w Iraku, gdzie strefa kontrolowana przez Kurdów jest dziś oazą spokoju i dobrobytu.

\section{PROCESY SĄDOWE JAKO KONSEKWENCJA OPERACJI AL-ANFAL}

Proces w sprawie operacji Al-Anfal prowadzony był przez Najwyższy Iracki Trybunał Karny (wcześniej Iracki Trybunał Nadzwyczajny ds. zbrodni przeciwko ludzkości), który został powołany przez Tymczasową Iracką Radę Zarządzającą 10 grudnia $2003 \mathrm{r}$. 
Trybunał miał osądzić zbrodniarzy oskarżonych o ludobójstwo, zbrodnie wojenne i zbrodnie przeciwko ludzkości. Trybunał prowadził sprawy przeciwko Irakijczykom mieszkających zarówno w Iraku, jak i poza jego granicami dotyczące zbrodni popełnianych w okresie między 17 lipca 1968 roku (moment dokonania przewrotu przez partię Al-Baas oraz przejęcia przez nią władzy w Iraku), a 1 maja 2003 r. Iracki parlament powołany na mocy konstytucji z 2005 roku wydał ustawę zatwierdzającą ważność dotychczasowych decyzji trybunału, a Rada Prezydencka podpisała tę ustawę (Al-Fadil, 2013).

Proces w sprawie operacji Al-Anfal rozpoczął się 21 sierpnia $2006 \mathrm{r}$. i prowadzony był przeciwko Saddamowi Husajnowi i Alemu Hasanowi Al-Madżidowi oraz ich współpracownikom. Zostali oni oskarżeni o ludobójstwo dokonane na 182 tysiącach Kurdów podczas operacji Al-Anfal. Podczas procesu oskarżeni nie przyznali się do winy, zaś Saddam Husajn oświadczył, że istnienie tego sądu jest niezgodne z prawem. W wyniku prowadzonego postępowania 24 czerwca $2007 \mathrm{r}$. sąd wydał następujące wyroki: Ali Hasan al-Madżid, ówczesny minister obrony Sultan Hashim Ahmad oraz zastępca szefa sztabu irackich sił zbrojnych Husajn Rashid al-Takriti zostali skazani na karę śmierci przez powieszenie, natomiast generałowie tajnych służb wojskowych Farhan al-Jubouri i Sabir Abdul Aziz Al-Douri zostali skazani na karę dożywotniego więzienia, zaś oskarżenia wobec ostatniego ze współpracowników Husajna Tahira al-Aniego zostały uchylone z powodu braku wystarczających dowodów. Postępowanie wobec Saddama Husajna zostało umorzone, ponieważ został on wcześniej powieszony zgodnie z wyrokiem sądu wydanym w sprawie Al-Dujail (BBC Arabic, 2007).

Procesy dotyczące Saddama Husajna i innych oskarżonych były krytykowane zarówno przez niektóre środowiska irackie i arabskie, jak i międzynarodowe. Krytyka dotyczyła w szczególności faktu, iż Saddam Husajn został skazany na karę śmierci podczas procesu w sprawie Al-Dujail ${ }^{3}$ za zbrodnię o stosunkowo niewielkim znaczeniu w porównaniu do innych dokonanych przez niego zbrodni, takich jak choćby ludobójstwo na Kurdach (Rostayi, 2007). Według prawnika, członka Regionalnego Parlamentu Kurdyjskiego, Zany Rostayiego i innych osób krytykujących przebieg procesów sądowych, to Stany Zjednoczone chciały, by skazanie Husajna odbyło się zanim zapadnie wyrok w sprawie $A l$-Anfal, tak aby nie mógł on ujawnić źródeł pochodzenia broni chemicznej użytej w tej operacji, którą dostarczały mu firmy z państw zachodnich. Wówczas bowiem odpowiedzialni za dostarczanie Husajnowi broni chemicznej mogliby zostać postawieni przed Międzynarodowym Trybunałem Karnym w Hadze (Ibidem).

Zwłaszcza mieszkańcy sunnickiej części Iraku (,od zawsze” wierni wobec Husajna), jak i z innych krajów arabskich, uważali że sama działalność sądu jest nielegalna, gdyż działa on pod zwierzchnictwem nominowanej przez prezydenta USA i dowodzonej przez Paula Bremera tymczasowej koalicyjnej administracji cywilnej w okupowa-

3 Termin pierwszego posiedzenia sądu w sprawie Al-Dujail został ustalony na dzień 19 października 2005 r. Podczas tego posiedzenia trybunał postawił w stan oskarżenia Saddama Husajna i czterech innych jego współpracowników, stawiając im zarzut zabicia 148 szyickich cywilów w miejscowości Al-Dujail w lipcu 1982 r. w odwecie za atak na konwój, w którym znajdował się sam iracki prezydent. 5 listopada 2006 r. zapadły wyroki skazujące na karę śmierci przez powieszenie Saddama Husajna, Barzana Ibrahima al-Hasana - ówczesnego szefa tajnych służb, oraz Awwada al-Saduna - ówczesnego sędziego Sądu Rewolucyjnego. Inni oskarżeni w tej sprawie otrzymali kary od 15 lat pozbawienia wolności aż do dożywotniego więzienia. 
nym przez Stany Zjednoczone Iraku. Dodatkowym argumentem stawianym na korzyść irackiego dyktatora była jego otwarta niechęć wobec Izraela i poparcie dla sprawy Palestyńczyków.

Szeroko krytykowana również była anarchia panująca na procesach sądowych, podczas których to oskarżeni w manifestacyjny sposób zarzucali sędziom „współpracę z okupantem”. Same zaś procesy toczyły się także po części według prawa irackiego, a po części według prawa międzynarodowego, a sami sędziowie zostali wcześniej przeszkoleni przez specjalistów w dziedzinie prawa Stanów Zjednoczonych. Prawa do transmisji procesów sądowych uzyskała firma amerykańska, zaś same procesy transmitowane były z dwudziestominutowym opóźnieniem w stosunku do ich rzeczywistego przebiegu tak, by umożliwić usunięcie wypowiedzi oskarżonych, które mogły być niewygodne dla administracji USA lub nowych władz Iraku (Ibidem).

Szereg zarzutów wobec Irackiego Trybunału Nadzwyczajnego już w momencie jego powołania wysunęła także Human Rights Watch. Krytyka dotyczyła w znaczącej mierze procedur, które miały być stosowane podczas procesów, oraz wymogu, by wszyscy sędziowie biorący w nich udział byli irackiego pochodzenia. Procedury nie przewidywały więc powoływania sędziów międzynarodowych lub niezależnych doradców, a według HRW, irackim sędziom, którzy mieli przewodniczyć procesom brakowało doświadczenia i wiedzy potrzebnej do sądzenia w sprawach dotyczących najcięższych zbrodni przewidywanych w kodeksach karnych (Flaws, 2003).

Unia Europejska nie skrytykowała samego przebiegu procesów, natomiast sprzeciwiła się wykonaniu kary śmierci na skazanych zbrodniarzach.

Większość krajów zachodnich uznała wyroki za sprawiedliwe i przyjęła z ulgą wydane przez sędziów werdykty.

Choć bez wątpienia sądy w państwach Bliskiego Wschodu, w tym w Iraku, są upolitycznione, a ich procedury nieprzejrzyste, ówczesne władze Iraku starały się nie interweniować w przebieg procesów sądowych wiedząc, że bez względu na to przed jakim sądem stanąłby Saddam Husajn, mając na uwadze ilość zgromadzonych dowodów, wyrok wydany w jego sprawie byłby zapewne najsurowszym możliwym wyrokiem. Jednak biorąc pod uwagę fakt, że w prawie międzynarodowym najsurowszą karą jest kara dożywotniego pozbawienia wolności, a Amerykanom i nowym władzom irackim zależało na śmierci dyktatora, było im na rękę, że Husajn sądzony był według prawa irackiego, które przewiduje karę śmierci. Fakt, że ówczesne władze irackie nie czekały z wykonaniem wyroku na Saddamie Husajnie do zakończenia procesów o ludobójstwo, oraz że egzekucja została wykonana w pierwszy dzień muzułmańskiego Święta Ofiarowania (Id al-Adha) 30 grudnia 2006 r. nadały temu wyrokowi polityczny charakter. W kwietniu 2008 r. parlament iracki uznał operację Al-Anfal za ludobójstwo. Innymi krajami, które również uznały tę operację za ludobójstwo były Szwecja, Norwegia i Wielka Brytania. Regionalny rząd kurdyjski podejmuje wysiłki, by ONZ oraz Unia Europejska oficjalnie uznały operację Al-Anfal za ludobójstwo.

Ludobójstwo dokonane na Kurdach przez reżim iracki w latach 1986-1988 (zwłaszcza sprawa Halabdży) przyniosło paradoksalny i nieoczekiwany przez S. Hu- 
sajna rezultat, przyczyniając się do umiędzynarodowienia kwestii kurdyjskiej i zwrócenia uwagi opinii publicznej na los Kurdów. Pośrednio ich dramat przyczynił się także do poprawy sytuacji ludności kurdyjskiej zamieszkującej inne kraje Bliskiego Wschodu. W samym Iraku dobrze ulokowane inwestycje w ropę naftową pozwoliły na zwiększenie przychodu krajowego. Od 2003 roku dochód z wydobycia ropy przyznany Kurdom z budżetu państwa wynosi $17 \%$. Pieniądze trafiają na rozwój infrastruktury oraz odszkodowania dla ofiar byłego reżimu irackiego. Pomoc państwa trafia również do tych osób, które przeżyły ataki chemiczne, ponieważ potrzebują one stałego nadzoru lekarza oraz specjalnej opieki medycznej z powodu chorób skóry, górnych dróg oddechowych i innych. Należy dodać, że państwowe szpitale często nie są w stanie pomóc tym ludziom, tak więc, szukają oni pomocy niekiedy w szpitalach innych państw.

Powstawać zaczęły również komisje badające zbiorowe mogiły ofiar pochowanych na terenach niezamieszkałych, wokół miast i mniejszych miejscowości Samarra, Nasiriya, Maysan, Diwaniya, Basra, Mosul, Hatra, Gayara, Kirkuk. Dane te wskazują, że masowe groby rozsiane są na terenie całego Iraku, co czyni kraj jedną, wielką, zbiorową mogiłą (Sulaivani, 2004: 11).

W marcu 2014 roku rząd regionalny Kurdystanu irackiego ustanowił Halabdżę czwartym muhafazatem, a dziewiętnastym w całym Iraku (Zengene, 2014). Kurdom udało się udowodnić, że rzeczywiście są partnerem państw zachodnich, czego dowodzi chociażby ich walka przeciwko dżihadystom z Państwa Islamskiego w Iraku i Lewancie w 2014 roku. Współpraca ta jest na tyle zaawansowana, że w dobie walki z terroryzmem w Iraku i Syrii państwa Zachodu szkolą oddziały armii kurdyjskiej i bezpośrednio dozbrajająje w ciężki sprzęt (nie zwracając się o zgodę do władz irackich). Prowadzone są także ataki z powietrza na pozycje dżihadystów dzięki skoordynowanemu działaniu sztabów sił kurdyjskich i państw zachodnich. Obecnie federalny Kurdystan jest częścią irackiej quasi konfederacji państwowej, a nawet de facto niezależnym bytem politycznym.

\section{Bibliografia}

Ahali Kurdystan al-Irak yoosharikune fi marasim defn 730 min dahaya al-anfal fi as-Sulajmanijja (Ludzie z irackiego Kurdystanu sq zaangażowani w uroczystości pochówku 730 ofiar al-Anfal w Sulajmanijja), Kuwait News Agency (KUNA), http://www.kuna.net.kw/ArticleDetails.aspx?id=2243637\&language $=$ ar (14.04.2014).

Akrayi M. (2011), Anfal and Halabja: the Kurdish Genocide in Iraq, „Ekurd Daily”, http://www.ekurd.net/mismas/articles/misc2011/3/state4861.htm (20.12.2014).

al-Akrad aaqebe tahrir al-kuwajt aam 1991 (Kurdowie po wyzwoleniu Kuwejtu w 1991 r.), „Al-Moqatel", http://www.moqatel.com/openshare/Behoth/Siasia21/Akrad/sec06.doc_cvt.htm(12.12.2014).

al-Fadil M., Al-asar al-qanuniya li Jaraim al-Anfal (Konsekwencje prawne zbrodni al-Anfal), „Modern Discussion”, http://m.ahewar.org/s.asp?aid=349774\&r=0\&cid=0\&u=\&i=0\&q= (20.12.2014).

al-Hazraji N. A. F. (2014), Al-harb al.-irakiya-al.-iraniya 1980-1988 (Wojna iracko-irańska 1980-1988), Bejrut.

al-Mas'ala al-kurdiya fi al-iraq (Sprawa kurdyjska w Iraku), http://www.moqatel.com/openshare/Behoth/Siasia21/Akrad/sec05.doc_cvt.htm (10.03.2014). 
al-tasalsul al-zameni fi qadiyat al-Anfal (Chronologia procesu w sprawie al-Anfal), BBC Arabic, http://news.bbc.co.uk/hi/arabic/middle_east_news/newsid_5386000/5386616.stm (20.12.2014).

Bulloch J., Morris H. (1991), Wojna Saddama, Poczatki konfliktu kuwejckiego i reakcja międzynarodowa, Poznań.

Clary D. E. (1994), Operation provide comfort - a strategic analysis, Alabama, http://www.dtic.mil/ $\mathrm{dtic} / \mathrm{tr} /$ fulltext/u2/a280675.pdf (18.02.2014).

Dziekan M. (2002), Historia Iraku, Warszawa.

Flaws in the New Iraqi Special Tribunal (2003), Human Rights Watch, http://www.hrw.org/legacy/english/docs/2003/12/19/iraq6770.htm (28.12.2014).

Galbraith P. W. (2006), The end of Iraq, Ain al.-Tine (j. arabski).

Iraq 's Crime of Genocide. The Anfal Campaign against the Kurds (1993), Human Rights Watch/Middle East, New York-Washington-Los Angeles-London, http://www.pasok.eu/pdf/Genocide.pdf.

Jomma F. (2001), Kurdowie i Kurdystan, Gdańsk.

Kelly M. J. (2008), Ghosts of Halabja: Saddam Hussein and the Kurdish Genocide, Westport, Connecticut-London.

Koivunen K. (2013), The Kurds, A Nation of Genocides, Stockholm.

Lemkin R. (2013), Rzqdy państw Osi w okupowanej Europie, Warszawa.

Muhammad S. A. (2011), Mawqif al-duwal al-arabiya min al-harb al-irakiya-al-iraniya (Stanowisko państw arabskich wobec wojny iracko-irańskiej), Basra.

Mukhemer F. U. (1999), Alaqet al-akrad bi al-wilayat al-mutahida al-amarikiya (Relacja Kurdów ze Stanami Zjednoczonymi Ameryki), „Al-Ahram”, http://digital.ahram.org.eg/articles.aspx?Serial $=219348 \&$ eid $=269$ (12.12.2014).

Resolution 678 (1990) adopted by the Security Council on 19 November 1990, S/RES/678 (1990), 29.11.1990.

Resolution 688 (1991) adopted by the Security Council on 5 April 1991, S/RES/688 (1991), 5.04.1991.

Resolution 986 (1995) adopted by the Security Council at its 3519 $9^{\text {th }}$ meeting on 14 April 1995, S/RES/986 (1995), 14.04.1995.

Rostayi Z. L., Was Saddam Hussein's Execution Legal?, „Niqash”, http://www.niqash.org/articles/?id=1780\&lang=en (20.12.2014).

Sprawa kurdyjska w Iraku, http://www.moqatel.com/openshare/Behoth/Siasia21/Akrad/sec05.doc_cvt.htm, (10.03.2014).

Sulaivani M. I. (2004), Human Rights Violations and Mass Graves in Iraq Under the Ba'athist-Saddam's Regime, w: W kręgu problematyki Kurdów i Kurdystanu, (red.) A. Abbas, Poznań.

Zebari A. H. (2013), Iraqi Kurds Seek Recognition of Genocide by Saddam, „Almonitor”, http://www.al-monitor.com/pulse/originals/2013/03/iraq-kurds-genocide.html\# (20.12.2014).

Zengene M. (2014), Barzani yooqiaa mersoom iaalan Halabdża muhafaza (Barzani podpisuje dekret o ogłoszeniu prowincji Halabdż), ,asherq alawsat”, nr 12893, http://www.aawsat.com/details.asp?section=4\&issueno=12893\&article=765011\&feature=\#.UzCpi84Wmt8 (17.03.2014).

\section{STRESZCZENIE}

Problem ludobójstwa w irackim Kurdystanie stanowi apogeum konfliktu iracko-kurdyjskiego sięgającego początku lat 20. XX wieku. Nacjonalistyczna partia Al-Baas, która doszła do władzy w 1963 r., zaczęła prowadzić represyjną politykę wobec Kurdów polegającą na wysie- 
dleniach z rdzennych obszarów na terytoria zamieszkałe przez ludność arabską lojalną wobec rządu. Kolejnymi krokami skierowanymi przeciw mniejszości kurdyjskiej było zorganizowane, masowe niszczenie i konfiskata jej mienia, ponadto zakaz przebywania w strefach wydzielonych przez władze, a także czystki etniczne na dużą skalę. Liczbę Kurdów, którzy padli ofiarą reżimu Saddama Husajna szacuje się na 182 tysiące. Użycie broni chemicznej w miejscowości Halabdża spowodowało śmierć ponad 5 tysięcy Kurdów, a ci którzy ocaleli do dziś odczuwają skutki tego ataku. To właśnie ta zbrodnia doprowadziła do umiędzynarodowienia kwestii kurdyjskiej, a w konsekwencji do uniezależnienia obszarów kurdyjskich od Bagdadu w latach 90. XX wieku. Niemal wszyscy autorzy ataku chemicznego oraz innych zbrodni na Kurdach zostali postawieni przed sądem i skazani za popełnione czyny.

\title{
KURDISH GENOCIDE IN IRAQI KURDISTAN IN THE 1980s AND ITS SUCCESIVE INTERNALIZATION
}

\begin{abstract}
Kurdish genocide in Iraqi Kurdistan marked a turning point in Iraqi-Kurdish conflict which dates back to the beginning of the $20^{\text {th }}$ century. Iraqi nationalist party, Al-Baas, which took over power in 1963 introduced a policy of repressions against Kurds and was successively displacing them from their indigenous areas to the territory inhabited by Arab population who was loyal to the government. Iraqi government was destroying and confiscating the property of the Kurdish minority on a massive and organized scale. It banned Kurds from staying in designated prohibited zones, and carried out massive scale ethnic cleansing. The number of Kurds who fell victim to the regime of Saddam Hussein is estimated at 182 thousand. Chemical attack in the town of Halabja killed over 5 thousand people and those who survived still feel the impact of this deadly attack. It was exactly Halabja chemical attack that led to the internalization of the Kurdish problem and finally to the emergence of an independent Kurdish autonomy protected by international forces under the auspices of the United Nations. Following the collapse of Iraqi regime in 2003, nearly all authors of the chemical attack and other crimes against Kurds were brought to court and sentenced.
\end{abstract}

